\title{
Tattoo-Associated Basal Cell Carcinoma: Coincident or Coincidence
}

\author{
Philip R. Cohen ${ }^{a, b} \quad$ Christof P. Erickson ${ }^{c} \quad$ Nathan S. Uebelhoer ${ }^{a}$ \\ Antoanella Calame ${ }^{c}$ \\ a San Diego Family Dermatology, National City, CA, USA; ${ }^{b}$ Department of Dermatology, \\ Touro University California College of Osteopathic Medicine, Vallejo, CA, USA; \\ ${ }^{c}$ Compass Dermatopathology, San Diego, CA, USA
}

\section{What Is It about?}

Tattoos are an expression of decorative body art. Basal cell carcinoma is a skin cancer associated with exposure to ultraviolet radiation. The development of a basal cell carcinoma within a tattoo is rare. This report describes a man with tattoo-associated basal cell carcinoma. The features of this man and the other 13 patients with basal cell carcinoma within their tattoo are summarized. Salient hypotheses are discussed regarding whether the tattoo influences the pathogenesis of the basal cell carcinoma or this phenomenon occurs merely by chance.

\section{Keywords}

Basal cell carcinoma $\cdot$ Cancer $\cdot$ Carcinoma $\cdot$ Cell $\cdot$ Tattoo

\begin{abstract}
Tattoos may be associated with medical complications including, albeit rarely, skin cancer. The features of a 46-year-old man who developed a basal cell carcinoma within a tattoo on his left scapula are described and the characteristics of the other 13 patients ( 7 men and 6 women) with tattoo-associated basal cell carcinoma are reviewed. The tumor usually occurs on the sun-exposed skin of individuals aged 60 years and older whose tattoo has often been present for 20 years or more. The pathogenesis of a basal cell carcinoma developing within a tattoo may merely be a coincidence. However, there is supporting evidence that the tattoo and the subsequent basal cell carcinoma may be coincident events whereby either tattoo injectionassociated trauma or the tattoo pigments and dyes (in their native state or after ultraviolet radiation alteration) or both have a carcinogenic impact on the development of the basal cell carcinoma at that location.




\section{Established Facts}

- Tattoos can be associated with various cutaneous events including dermatitis, granulomatous dermatoses, and infections.

- Cutaneous malignancies, such as squamous cell carcinoma and melanoma, can develop in tattoos.

\section{Novel Insights}

- Basal cell carcinoma arising within a tattoo is rare; including the reported patient, tattooassociated basal cell carcinoma has only been described in 14 individuals.

- The development of basal cell carcinoma in a tattoo may be multifactorial, related not only to ultraviolet radiation exposure but also to carcinogens from the tattoo pigments and dyes.

\section{Introduction}

Tattoos are created by injecting exogenous pigments and dyes into the dermis [1]. Basal cell carcinoma is a nonmelanoma skin cancer that originates in the epidermis [2]. The development of a basal cell carcinoma within a tattoo is rare [3].

A man with a linear basal cell carcinoma that appeared within his tattoo is described. The features of other individuals with tattoo-associated basal cell carcinoma are reviewed. Whether the development of a basal cell carcinoma within an existing tattoo is coincident with the existence of the acquired skin pigmentation or merely a coincidence is discussed.

\section{Case Report}

A 46-year-old Caucasian man presented for a total body skin check. He had numerous tattoos that occupied approximately $40 \%$ of his body surface area, including his arms, legs, and back. His past medical history was significant for an aortic valve replacement $4 \frac{1}{2}$ years ago and an aortic aneurysm repair $1 \frac{1}{2}$ years ago.

His dermatologic history was significant for actinic keratoses that were treated with liquid nitrogen cryotherapy. He also had 2 nonmelanoma skin cancers: a squamous cell carcinoma in situ on his left forearm $1 \frac{1 / 2}{2}$ years ago and a superficial basal cell carcinoma on his left chest 1 year ago. Both of the skin cancers were excised using the Mohs micrographic surgical technique; there had not been any recurrence of the tumors on follow-up examinations.

Cutaneous examination showed an asymptomatic, $12 \times 6 \mathrm{~mm}$ linear plaque with central ulceration on the skin overlying his left scapula (Fig. 1). The lesion had been present for $1 \frac{1}{2}$ years and initially was painful. It currently was nontender and extended from an underlying black tattoo onto skin that did not contain a tattoo. The tattoo had been present for 20 years.

A 4-mm punch biopsy was performed from the portion of the lesion that was overlying the tattoo. Microscopic examination demonstrated a crusted ulceration surrounded by an irregular epidermis. Extending from the overlying epidermis into the dermis, there were nodular masses of basal neoplastic cells with small hyperchromatic nuclei, nuclear pleomor- 

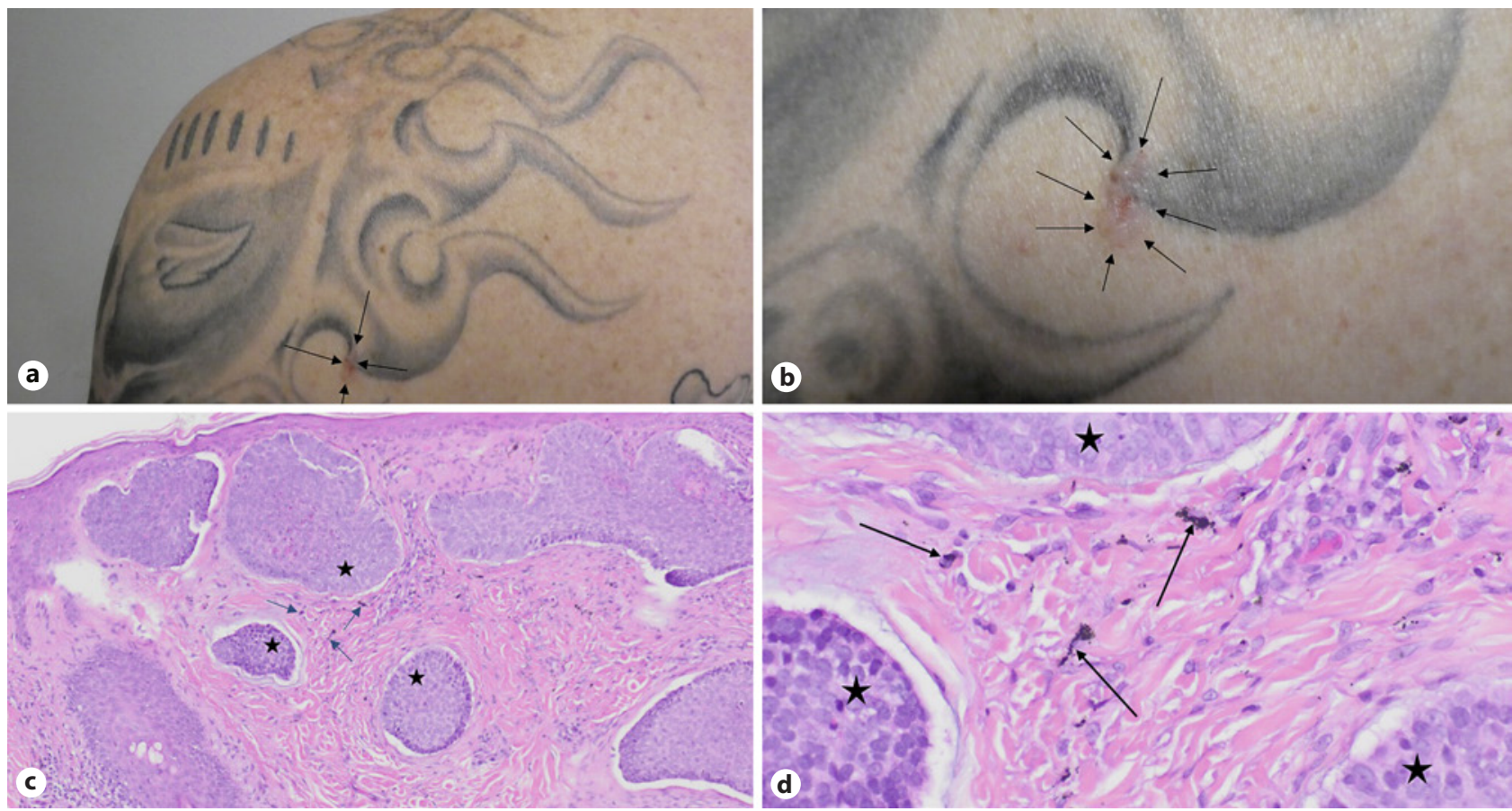

Fig. 1. Distant (a) and closer (b) views of the clinical presentation of a tattoo-associated basal cell carcinoma on the left scapula area of the upper back; a linear nodule (black arrows) extends from the inferior edge of the tattoo. Distant (c) and closer (d) views of microscopic features of tattoo-associated basal cell carcinoma show nodular aggregates of basaloid tumor cells (black stars) extending from the epidermis into the underlying dermis; the tattoo pigment (blue arrows) appears as small black amorphous particles in the dermis (hematoxylin and eosin: $\mathbf{c} \times 4 ; \mathbf{d} \times 20$ ).

phism, scanty cytoplasm, and peripheral palisading of nuclei. Neutrophils and other inflammatory cells were seen around the ulceration and in the tumor stroma. There was also exogenous pigment representing tattoo in the dermis (Fig. 1).

Correlation of the patient's history, clinical presentation, and pathologic findings established a diagnosis of tattoo-associated basal cell carcinoma. The residual tumor will be excised using the Mohs micrographic surgical technique.

\section{Discussion}

Tattooing results in pigmentation of the skin [4]. Tattoos are often an expression of decorative body art [5]. However, they are also utilized for medical management to outline the areas of treatment in radiation oncology and for postoperative treatment to provide aesthetic restoration of the areola and nipple following mastectomy in oncology patients [6].

Cutaneous adverse events associated with tattoos include hypersensitivity reactions to the tattoo pigments and dyes, infectious disorders (such as bacteria, fungus, mycobacteria, and viral infections), granulomatous reactions (including sarcoidosis, sarcoidal granulomas, and granuloma annulare) and skin conditions (such as lichen planus, lupus erythematosus, morphea, and psoriasis) [7-11]. Cancers have also appeared within tattoos [12]. These include not only nonmelanoma skin cancers such as basal cell carcinoma, keratoacanthoma, and squamous cell carcinoma but also melanoma, leiomyosarcoma, and dermatofibrosarcoma protuberans [13]. 
Table 1. Features of patients with tattoo-associated basal cell carcinomas

\begin{tabular}{|c|c|c|c|c|c|}
\hline $\begin{array}{l}\text { Case } \\
\text { [Ref.] }\end{array}$ & $\begin{array}{l}\text { Epi: } \\
\text { A/Ra } \\
\text { Sex }\end{array}$ & $\begin{array}{l}\text { Tattoo: } \\
\text { Duration } \\
\text { Color }\end{array}$ & $\begin{array}{l}\text { BCC: } \\
\text { Duration } \\
\text { Location }\end{array}$ & $\begin{array}{l}\text { Clinical appearance of BCC: } \\
\text { Size, mm/color } \\
\text { Morphology }\end{array}$ & $\begin{array}{l}\text { Path } \\
\text { Tx }\end{array}$ \\
\hline $\begin{array}{l}1 \\
{[17]}\end{array}$ & $\begin{array}{l}28 / \mathrm{Ca} \\
\mathrm{W}\end{array}$ & $\begin{array}{l}6 \text { years } \\
\text { Black }\end{array}$ & $\begin{array}{l}\text { NS } \\
\text { Central back }\end{array}$ & $\begin{array}{l}6 \times 6 / \text { pearly and telangiectasia } \\
\text { Nodule }\end{array}$ & $\begin{array}{l}\text { Nod } \\
\text { Ex }\end{array}$ \\
\hline $\begin{array}{l}2 \\
{[18]}\end{array}$ & $\begin{array}{l}35 / \mathrm{NS} \\
\mathrm{M}\end{array}$ & $\begin{array}{l}1 \text { year } \\
\text { NS }\end{array}$ & $\begin{array}{l}\text { NS } \\
\text { L scapula }\end{array}$ & $\begin{array}{l}7 \times 7 / \text { red } \\
\text { Infiltrated papule }\end{array}$ & $\begin{array}{l}\text { Pag } \\
\text { Ex }\end{array}$ \\
\hline $\begin{array}{l}3 \\
{[19]}\end{array}$ & $\begin{array}{l}40 / \mathrm{Ca} \\
\mathrm{M}\end{array}$ & $\begin{array}{l}7 \text { years } \\
\text { Blue }\end{array}$ & $\begin{array}{l}4.5 \text { years } \\
\text { Back }\end{array}$ & $\begin{array}{l}\text { NS/NS } \\
\text { NS }\end{array}$ & $\begin{array}{l}\text { Sup } \\
\text { Ex }\end{array}$ \\
\hline $\begin{array}{l}4 \\
{[3]}\end{array}$ & $\begin{array}{l}41 / \mathrm{Ca} \\
\mathrm{M}\end{array}$ & $\begin{array}{l}12 \text { years } \\
\text { NS }\end{array}$ & $\begin{array}{l}0.83 \text { years } \\
\mathrm{L} \text { forearm }\end{array}$ & $\begin{array}{l}15 \times 7 / \text { brown, red } \\
\text { Plaque }\end{array}$ & $\begin{array}{l}\text { Nod } \\
\text { MMS }\end{array}$ \\
\hline $\begin{array}{l}5 \\
\mathrm{CR} \\
\end{array}$ & $\begin{array}{l}46 / \mathrm{Ca} \\
\mathrm{M}\end{array}$ & $\begin{array}{l}20 \text { years } \\
\text { Black }\end{array}$ & $\begin{array}{l}1.5 \text { years } \\
\text { L scapula }\end{array}$ & $\begin{array}{l}12 \times 6 / \text { skin-colored } \\
\text { Ulcerated linear plaque }\end{array}$ & $\begin{array}{l}\text { Nod } \\
\text { MMS }\end{array}$ \\
\hline $\begin{array}{l}6 \\
{[20], C 2}\end{array}$ & $\begin{array}{l}52 / \mathrm{Ir} \\
\mathrm{M}\end{array}$ & $\begin{array}{l}15 \text { years } \\
\text { Black }\end{array}$ & $\begin{array}{l}4 \text { years } \\
\text { R temple }\end{array}$ & $\begin{array}{l}\text { NS/NS } \\
\text { Ulcerated lesion }\end{array}$ & $\begin{array}{l}\text { NOS } \\
\text { Ex }\end{array}$ \\
\hline $\begin{array}{l}7 \\
{[20], \text { C1 }}\end{array}$ & $\begin{array}{l}60 / \mathrm{Ir} \\
\mathrm{W}\end{array}$ & $\begin{array}{l}20 \text { years } \\
\text { Black }\end{array}$ & $\begin{array}{l}3 \text { years } \\
\text { R temple }\end{array}$ & $\begin{array}{l}7-8 \times 7-8 / \mathrm{NS} \\
\text { Ulcer }\end{array}$ & $\begin{array}{l}\text { NOS } \\
\text { Ex }\end{array}$ \\
\hline $\begin{array}{l}8 \\
{[21]}\end{array}$ & $\begin{array}{l}60 / \text { Ko } \\
\text { W }\end{array}$ & $\begin{array}{l}5 \text { years } \\
\text { Black }\end{array}$ & $\begin{array}{l}2 \text { years } \\
\text { L eyebrow }\end{array}$ & $\begin{array}{l}10 \times 13 / \text { Skin-colored and trans } \\
\text { Papule and sclerotic dprs patch }\end{array}$ & $\begin{array}{l}\text { N\&S } \\
\text { MMS }\end{array}$ \\
\hline $\begin{array}{l}9 \\
{[22], C 2}\end{array}$ & $\begin{array}{l}64 / \text { In } \\
\text { W }\end{array}$ & $\begin{array}{l}30 \text { years } \\
\text { Blue }\end{array}$ & $\begin{array}{l}1.17 \text { years } \\
\text { Upper lip }\end{array}$ & $\begin{array}{l}10 \times 10 / \text { pearly } \\
\text { Crusting nodular plaque }\end{array}$ & $\begin{array}{l}\text { Nod } \\
\text { NS }\end{array}$ \\
\hline $\begin{array}{l}10 \\
{[23], \mathrm{C} 2}\end{array}$ & $\begin{array}{l}\text { 64/NS } \\
\mathrm{M}\end{array}$ & $\begin{array}{l}40 \text { years } \\
\text { Black }\end{array}$ & $\begin{array}{l}\text { NS } \\
\text { R dorsal hand }\end{array}$ & $\begin{array}{l}\text { NS/NS } \\
\text { Ulcer }\end{array}$ & $\begin{array}{l}\text { NOS } \\
\text { NS }\end{array}$ \\
\hline $\begin{array}{l}11 \\
{[24]}\end{array}$ & $\begin{array}{l}64 / \mathrm{Ca} \\
\mathrm{M}\end{array}$ & $\begin{array}{l}46 \text { years } \\
\text { Blue, green }\end{array}$ & $\begin{array}{l}\text { NS } \\
\text { L forearm }\end{array}$ & $\begin{array}{l}\text { NS/pearly } \\
\text { Nodule }\end{array}$ & $\begin{array}{l}\text { NOS } \\
\text { NS }\end{array}$ \\
\hline $\begin{array}{l}12 \\
{[22], \mathrm{C} 1}\end{array}$ & $\begin{array}{l}72 / \text { In } \\
\text { W }\end{array}$ & $\begin{array}{l}\text { Many years } \\
\text { Black, blue }\end{array}$ & $\begin{array}{l}1 \text { year } \\
\text { Upper lip }\end{array}$ & $\begin{array}{l}20 \times 20 / \text { brown, red } \\
\text { Ulcerated ped umb-s nodule }\end{array}$ & $\begin{array}{l}\text { Nod } \\
\text { NS }\end{array}$ \\
\hline $\begin{array}{l}13 \\
{[23], \mathrm{C} 1}\end{array}$ & $\begin{array}{l}\text { 76/NS } \\
\mathrm{M}\end{array}$ & $\begin{array}{l}57.5 \text { years } \\
\text { Red }\end{array}$ & $\begin{array}{l}2.5 \text { years } \\
\text { R shoulder }\end{array}$ & $\begin{array}{l}\text { NS/NS } \\
\text { Ulcerated lesion }\end{array}$ & $\begin{array}{l}\text { Sup } \\
\text { Ex }\end{array}$ \\
\hline $\begin{array}{l}14 \\
{[25]}\end{array}$ & $\begin{array}{l}86 / \mathrm{Ca} \\
\mathrm{W}\end{array}$ & $\begin{array}{l}13 \text { years } \\
\text { Black, TB }\end{array}$ & $\begin{array}{l}7 \text { years } \\
\text { L lower eyelid }\end{array}$ & $\begin{array}{l}\text { NS/NS } \\
\text { Cystic lesion }\end{array}$ & $\begin{array}{l}N \& S \\
\text { Ex }\end{array}$ \\
\hline
\end{tabular}

a The duration of years the tattoo was present prior to diagnosis of basal cell carcinoma. ${ }^{\mathrm{b}}$ The duration of years the lesion was present prior to diagnosis of basal cell carcinoma. A, age (in years at the time of diagnosis of the basal cell carcinoma); BCC, basal cell carcinoma; C, case; Ca, Caucasian; CR, current report; dprs, depressed; Epi, epidemiology; Ex, excision; In, Iranian; Ir, Iraqi; Ko, Korean; L, left; M, man; MMS, Mohs micrographic surgery; Nod, nodular; NOS, not otherwise specified; NS, not stated; N\&S, nodular and sclerosing; Pag, pagetoid; Path, pathology (of basal cell carcinoma); Ped, pedunculated; R, right; Ra, race; Ref., reference; Sup, superficial; TB, turquoise-blue; Trans, translucent; Tx, treatment (of basal cell carcinoma); Umb-s, umbrella-shaped; W, woman.

Basal cell carcinoma is the most common type of skin cancer [14]. It typically occurs on sun-exposed areas of the body [15]. Although the clinical appearance of a basal cell carcinoma can be variable, the pathologic findings typically correspond to the particular tumor morphology [16].

Tattoo-associated basal cell carcinoma has seldom been reported. To the best of our knowledge, including the man described in this paper, basal cell carcinoma appearing in a 
tattoo has only been documented in 14 individuals $[3,17-25]$. The features of the patients with tattoo-associated basal cell carcinoma are summarized in Table 1 [3, 17-25].

There are 8 men and 6 women with tattoo-associated basal cell carcinomas. The patients' age ranged from 28 to 86 years (median, 60 years) when their basal cell carcinoma was diagnosed. The men were 35 to 76 years old (median, 49 years), whereas the women were 28 to 86 years old (median, 62 years).

The race was described in 11 patients. Most of the patients (55\%, 6 of 11) were Caucasian. The other patients were either Iranian ( 2 patients) or Iraqi ( 2 patients) or Korean (1 patient).

The duration of time the tattoo had been present was specified in years for 13 patients and ranged from 1 year to 57.5 years (median, 15 years); one patient's tattoo had been present for many years. More than half of the patients (7 of 13) had tattoos that had been present for 20 or more years. Only $31 \%$ ( 4 of 13) of the patients had their tattoos for less than 7 years prior to the development of the basal cell carcinoma.

Nearly all of the tattoos $(92 \%, 11$ of 12$)$ were dark; the color of the tattoo was not stated for two patients. Seventy five percent ( 9 of 12) of the tattoos were only 1 color; 3 tattoos were 2 colors: black and blue ( 2 patients) or blue and green (1 patient). Black was the most common tattoo color (67\%, 8 of 12 ). Other tattoo colors were blue ( 5 patients), green ( 1 patient), or red (1 patient).

The duration of time that the basal cell carcinoma had been present prior to diagnosis was available for 10 of the patients. It ranged from 10 months to 7 years (median, 2.5 years). Half of the tumors ( 5 of 10 ) had only been present for 2 years or less.

Tattoo-associated basal cell carcinomas typically presented as asymptomatic skin lesions (79\%, 11 of 14). However, 2 patients noticed that their tumor presented with pruritus. The 35 -year-old woman had an itching lesion that developed in the tattoo on her left scapula 1 year after tattooing [18], and the 40 -year-old man with a tattoo on his back for 7 years noticed pruritus localized to only part of his tattoo beginning 4 to 5 years before he sought further evaluation [19]. The reported patient's tumor was initially painful; however, during a period of $1 \frac{1}{2} 2$ years, the tumor became nontender and was asymptomatic at the time of diagnosis.

Tattoo-associated basal cell carcinomas were most commonly located on the face $(43 \%$, 6 of 14) and back (36\%, 5 of 14); they also occurred on the upper extremity (21\%, 3 of 14). The right temple (tattooed in an attempt to treat the patient's headaches) and the upper lip were each facial sites for 2 patients; other facial locations were the left eyebrow (1 patient) and the left lower eyelid ( 1 patient). The upper extremity sites included the left forearm (2 patients) and the right dorsal hand (1 patient).

The basal cell carcinoma ranged in size from $6 \times 6 \mathrm{~mm}$ to $20 \times 20 \mathrm{~mm}$ (median, $11 \times 8$ $\mathrm{mm}$ ). Some were pearly ( 2 patients) or brown and red ( 2 patients). Others had associated telangiectasias (1 patient), were translucent (1 patient), or were red (1 patient).

One patient had a basal cell carcinoma that demonstrated more than 1 morphology (a papule and a sclerotic depressed patch) and the morphology was not described for 1 patient. The tumor morphology of the other 12 patients included ulcers or ulcerated lesions (4 tumors), plaques (3 tumors, 1 of which was crusted and nodular and another that was ulcerated and linear), nodules ( 2 tumors, 1 of which was not only ulcerated but also pedunculated and umbrella-shaped), and papules ( 2 tumors, 1 of which was infiltrated) and a cystic lesion (1 tumor). Linear cutaneous malignancies - either melanoma or nonmelanoma skin cancers - similar to that observed on the reported patient, are not commonly described [26, 27].

The diagnosis of all of the tattoo-associated basal cell carcinomas was confirmed by biopsy or excision or both. The most common pathology subtype was nodular ( $50 \%, 5$ of 10 ). Other basal cell carcinoma pathology subtypes included superficial $(20 \%, 2$ of 10$)$ and pagetoid $(10 \%, 1$ of 10$)$. Two patients $(20 \%)$ had basal cell carcinomas with mixed histology: 
nodular and sclerosing [28]. The pathologic subtype was not otherwise stated for 4 of the patients.

Treatment was described for 10 of the patients. All of the tumors were surgically removed either by performing a routine excision ( 7 patients) or Mohs micrographic surgery (3 patients).

Basal cell carcinomas have a genomic aberration in the Hedgehog pathway; this is a targetable mutation for systemic oral therapeutic agents such as vismodegib and sonidegib in patients with advanced or metastatic tumors $[29,30]$. There are several risk factors for the development of basal cell carcinomas $[15,16]$. One of these is exposure to ultraviolet radiation; indeed, some of the patients with tattoo-associated basal cell carcinomas - such as the reported patient - also had a history of prior nonmelanoma skin cancer [25] or melanoma [19].

Some of the investigators have implied that the tattoo - either itself or during the process of its creation or following exposure to ultraviolet radiation - may have contributed to the pathogenesis of the basal cell carcinoma at this site [3, 17, 18, 21-23]. Indeed, 92\% (11 of 12) of the tattoos were darkly pigmented. The dark color of the tattoo may have altered the absorption of the ultraviolet radiation and increased the likelihood of tumor development in the overlying epidermis [24].

A few of the tattoos and their associated basal cell carcinomas were located in body areas that may not have received significant exposure to ultraviolet radiation. For example, the investigators who reported the 28-year-old woman with a basal cell carcinoma on her central back specifically commented that this was a site that had received less sun exposure and postulated that trauma was an etiologic factor in the development of her cancer [17]. Hence, the trauma associated with injection of the pigments and dyes may have altered the site in a manner to create a zone of increased immunologic susceptibility (also referred to as an immunocompromised cutaneous district) that enhanced the opportunity of a basal cell carcinoma to occur at that location $[31,32]$.

However, many of the tattoo-associated basal cell carcinomas developed in sun-exposed areas. Some of the materials used to create the tattoo pigments and dyes have been demonstrated to be carcinogenic either in their native form or following exposure to ultraviolet radiation. For example, the carbon used in black tattoos frequently has associated polycyclic aromatic hydrocarbons. The release of reactive oxygen species following absorption of ultraviolet radiation by the black tattoos may increase the risk of carcinogenesis at these locations [33-38].

Whether the pathogenesis of tattoo-associated basal cell carcinoma is a coincident occurrence involving a multifactorial etiology of basal cell carcinoma susceptibility combined with a carcinogen effect of the tattoo pigments and dyes or merely a coincidence of the cancer appearing on a sun-exposed site that also happens to be the location of a tattoo remains to be established. The investigators of 9 patients with tattoo-associated basal cell carcinomas including the reported patient - favor that this phenomenon is a coincident event $[3,17,18$, 21-23]. However, the researchers of 4 patients consider the development of a basal cell carcinoma in a tattoo to merely be due to chance alone $[19,20,25]$. One of the patient's physicians presented both alternatives but could not make a commitment to either possibility [24].

\section{Conclusion}

Tattoo-associated basal cell carcinomas are rare. This report describes a man who developed a basal cell carcinoma within the tattoo on the skin overlying his left scapula. Including this patient, tattoo-associated basal cell carcinomas have been reported in 14 
patients: 8 men and 6 women with a median age of 60 years. Nearly all (92\%) of the tattoos were dark and $54 \%$ had been present for more than 20 years. The basal cell carcinomas were usually asymptomatic (79\%), located on the face (43\%), back (36\%), and upper extremities (21\%), and present a median of 2.5 years prior to diagnosis. The tumors ranged in diameter from $6 \mathrm{~mm}$ to $2 \mathrm{~cm}$ and presented as an ulcer or ulcerated lesion (31\%), plaque (23\%), nodule $(15 \%)$, papule (15\%), cystic lesion (8\%), or papule with a sclerotic depressed patch (8\%). All of the cancers were surgically removed by routine excision $(70 \%)$ or Mohs micrographic surgery (30\%). The pathogenesis of tattoo-associated basal cell carcinoma remains to be definitively determined. Although some researchers suggest that a basal cell carcinoma developing within a tattoo may merely be a coincidence, many investigators have endorsed the supporting evidence that the trauma associated with tattoo injection and/or the tattoo pigments and dyes of the tattoos in either their native state or after ultraviolet radiation alteration have a carcinogenic role in the development of the basal cell carcinoma at that site and therefore, the tattoo and the subsequent basal cell carcinoma occurring at that location are coincident events.

\section{Statement of Ethics}

The patient has given his written informed consent to publish his case including publication of images.

\section{Conflict of Interest Statement}

P.R.C. is a paid consultant for ParaPRO. The other authors (C.P.E., N.S.U., and A.C.) have no conflicts of interest to declare.

\section{Funding Sources}

This research did not receive any funding from any funding agencies in the public, commercial, or not-for-profit sectors.

\section{Author Contributions}

P.R.C. and N.S.U. took care of the patient. C.P.E. and A.C. performed the dermatopathology. P.R.C. wrote the paper. All authors read and approved the report.

\section{References}

1 Kluger N. Acute complications of tattooing presenting in the ED. Am J Emerg Med. 2012 Nov;30(9):2055-63. 2 Cohen PR. Basal cell carcinoma. J Gt Houst Dent Soc. 1995 Aug;67(1):20-1.

3 Abudu B, Erickson CP, Calame A, Cohen PR. Basal cell carcinoma originating in a tattoo: case report and review of an uncommon complication in tattoo recipients. Dermatol Pract Concept. 2019 Oct;9(4):265-70.

4 Körner R, Pföhler C, Vogt T, Müller CS. Histopathology of body art revisited - analysis and discussion of 19 cases. J Dtsch Dermatol Ges. 2013 Nov;11(11):1073-80.

5 Laumann AE, Derick AJ. Tattoos and body piercings in the United States: a national data set. J Am Acad Dermatol. 2006 Sep;55(3):413-21.

6 Osborn LP, Cohen PR. Emotional healing with unconventional breast tattoos: the role of temporary tattoos in the recovery process after breast carcinoma and mastectomy. Clin Dermatol. 2018 May-Jun;36(3):426-9. 
7 Kluger N. Cutaneous complications related to permanent decorative tattooing. Expert Rev Clin Immunol. 2010 May;6(3):363-71.

8 Wenzel SM, Rittmann I, Landthaler M, Bäumler W. Adverse reactions after tattooing: review of the literature and comparison to results of a survey. Dermatology. 2013;226(2):138-47.

9 Kluger N. Cutaneous and systemic complications associated with tattooing. Presse Med. 2016 Jun; 45(6 Pt 1): 567-76.

10 Kluger N. Cutaneous complications related to tattoos: 31 cases from Finland. Dermatology. 2017;233(1): $100-9$.

11 Greywal T, Cohen PR. Cosmetic tattoo pigment reaction. Dermatol Online J. 2016 Jul;22(7):13030/qt3rc114rg.

12 Kluger N, Koljonen V. Tattoos, inks, and cancer. Lancet Oncol. 2012 Apr;13(4):e161-8.

13 Paprottka FJ, Krezdorn N, Narwan M, Turk M, Sorg H, Noah EM, et al. Trendy tattoos - maybe a serious health risk? Aesthetic Plast Surg. 2018 Feb;42(1):310-21.

14 Cohen PR. Basal cell carcinoma: additional subtypes and therapeutic advances. J Am Acad Dermatol. 2019 Jul; 81(1):e17.

15 Nikanjam M, Cohen PR, Kato S, Sicklick JK, Kurzrock R. Advanced basal cell cancer: concise review of molecular characteristics and novel targeted and immune therapeutics. Ann Oncol. 2018 Nov;29(11):2192-9.

16 Cohen BJ, Cohen ES, Cohen PR. Basal cell carcinoma: a patient and physician's experience. Dermatol Ther (Heidelb). 2018 Sep;8(3):329-37.

17 Birnie AJ, Kulkarni K, Varma S. Basal cell carcinoma arising in a tattoo. Clin Exp Dermatol. 2006 Nov;31(6): $820-1$.

18 Doumat F, Kaise W, Barbaud A, Schmutz JL. Basal cell carcinoma in a tattoo. Dermatology. 2004;208(2):181-2.

19 Kluger N, Phan A, Debarbieux S, Balme B, Thomas L. Skin cancers arising in tattoos: coincidental or not? Dermatology. 2008;217(3):219-21.

20 Bashir AH. Basal cell carcinoma in tattoos: report of two cases. Br J Plast Surg. 1976 Oct;29(4):288-90.

21 Lee JS, Park J, Kim SM, Yun SK, Kim HU. Basal cell carcinoma arising in a tattooed eyebrow. Ann Dermatol. 2009 Aug;21(3):281-4.

22 Omidian M, Emad-Mostofi N. Basal cell carcinoma arising from traditional tattoo. Arch Iran Med. 2009 Mar; 12(2):198.

23 Earley MJ. Basal cell carcinoma arising in tattoos: a clinical report of two cases. Br J Plast Surg. 1983 Apr;36(2): 258-9.

24 Wiener DA, Scher RK. Basal cell carcinoma arising in a tattoo. Cutis. 1987 Feb;39(2):125-6.

25 Messmer EM, Möhring-Bengisu C, Miller C. Lidline tattoo associated with basal cell carcinoma of the lid margin - coincidence or association? Klin Monbl Augenheilkd. 2018 Jul;235(7):785-8.

26 Chopra KF, Cohen PR. Linear basal cell carcinomas: report of multiple sequential tumors localized to a radiotherapy port and review of the literature. Tex Med. 1997 Jul;93(7):57-9.

27 Cohen PR. Linear malignant melanoma in situ: reports and review of cutaneous malignancies presenting as linear skin cancer. Cureus. 2017 Sep;9(9):e1696.

28 Cohen PR, Schulze KE, Nelson BR. Basal cell carcinoma with mixed histology: a possible pathogenesis for recurrent skin cancer. Dermatol Surg. 2006 Apr;32(4):542-51.

29 Cohen PR, Kurzrock R. Basal cell carcinoma: management of advanced or metastatic cancer with checkpoint inhibitors and concurrent paradoxical development of new superficial tumors. J Am Acad Dermatol. 2020 Jun; 82(6):e253-4.

30 Goodman AM, Kato S, Cohen PR, Boichard A, Frampton G, Miller V, et al. Genomic landscape of advanced basal cell carcinoma: implications for precision treatment with targeted and immune therapies. OncoImmunology. 2017 Dec;7(3):e1404217.

31 Ruocco V, Ruocco E, Piccolo V, Brunetti G, Guerrera LP, Wolf R. The immunocompromised district in dermatology: a unifying pathogenic view of the regional immune dysregulation. Clin Dermatol. 2014 Sep-Oct;32(5): 569-76.

32 Ruocco V, Brunetti G, Puca RV, Ruocco E. The immunocompromised district: a unifying concept for lymphoedematous, herpes-infected and otherwise damaged sites. J Eur Acad Dermatol Venereol. 2009 Dec;23(12): 1364-73.

33 Engel E, Ulrich H, Vasold R, König B, Landthaler M, Süttinger R, et al. Azo pigments and a basal cell carcinoma at the thumb. Dermatology. 2008;216(1):76-80.

34 Regensburger J, Lehner K, Maisch T, Vasold R, Santarelli F, Engel E, et al. Tattoo inks contain polycyclic aromatic hydrocarbons that additionally generate deleterious singlet oxygen. Exp Dermatol. 2010 Aug;19(8):e275-81.

35 Laux P, Tralau T, Tentschert J, Blume A, Dahouk SA, Bäumler W, et al. A medical-toxicological view of tattooing. Lancet. 2016 Jan;387(10016):395-402.

36 Engel E, Spannberger A, Vasold R, König B, Landthaler M, Bäumler W. Photochemical cleavage of a tattoo pigment by UVB radiation or natural sunlight. J Dtsch Dermatol Ges. 2007 Jul;5(7):583-9.

37 Engel E, Vasold R, Santarelli F, Maisch T, Gopee NV, Howard PC, et al. Tattooing of skin results in transportation and light-induced decomposition of tattoo pigments - a first quantification in vivo using a mouse model. Exp Dermatol. 2010 Jan;19(1):54-60.

38 Engel E, Santarelli F, Vasold R, Maisch T, Ulrich H, Prantl L, et al. Modern tattoos cause high concentrations of hazardous pigments in skin. Contact Dermat. 2008 Apr;58(4):228-33. 